\title{
Verbal prefixation and realizations of antipassive alternations in Polish
}

\author{
Katarzyna Mroczyńska \\ Siedlce University of Natural Sciences and Humanities, Poland
}

\begin{abstract}
Various works on transitivity suggest that aspectual notions may constitute semantic determinants of argument realization. Observations included in these works prompted theories implying that argument realization may be aspectually driven. Following this line of thought, this article presents the results of corpus-based studies on antipassive structure in the Polish language and makes an attempt at confirming the fact that aspectual notion may determine argument realization.

The article consists of three main sections. The first one focuses on notions of aspect and various aspectual propositions distinguished in the literature on the subject, regarding the Polish language in particular. The second section, illustrated with examples extracted from the National Corpus of Polish (NKJP) and the corpus of Wielki Słownik Języka Polskiego (KWSJP), gives an overview of Polish perfectivizing verbal prefixes, i.e. a roz-, na-, o-/oband $u$-prefix, and deals with the effect they may have on sentence structure and semantics. It also shows how the prefixed verbs combine with the marker sie, which flags antipassive, i.e. is a recurring marker attested in antipassive constructions in the Polish language. In section three, an attempt is made at analyzing the interrelations between aspect and antipassive reading of a structure. As it seems that a perfective prefix used with a verb imposes certain requirements on the argument structure of the verb it combines with, we also offer a possible explanation to different aspectual requirements of verbs occurring in antipassive structures, assuming that projections coded in a verb may play a role here. ${ }^{1}$
\end{abstract}

Keywords: antipassive, aspect, Polish, prefixing, verb projections

\section{Introduction}

This article takes as a starting point a relatively contemporary definition of antipassive provided by Polinsky (2005, p. 438), which implies that in antipassives the patient-like object is either totally erased from the sentence structure or moved to an oblique position:

1 Abbreviations: ACC - accusative, AP - antipassive, F - feminine, FUT - future, IMP - imperative, IMPERF imperfective, IMPER - impersonal, INSTR - instrumental, LOC - locative, $\mathrm{M}$ - masculine, N - neuter, NEG negation, NOM - nominative, OBL - oblique, PERF - perfective, PL - plural, PRES - present tense, PRN pronoun, PST - past tense, QW - question word, SIE - the verbal marker in Polish, SG - singular. 


\begin{abstract}
An antipassive construction is a derived detransitivized construction with a two-place predicate, related to a corresponding transitive construction whose predicate is the same lexical item. In the basic transitive construction, the patient like argument is realized as a direct object; in the antipassive construction, that argument is either suppressed (left implicit) or realized as an oblique complement. (Polinsky, 2005, p. 438)
\end{abstract}

As Polinsky (2017, pp. 311-314) argues in her more recent work, there is no single morphological diagnostic to test for antipassive. Still, it may be useful to point out several most noteworthy patterns that occur across languages, i.e. case-marking, where oblique often indicates the non-core status of the antipassive object; verbal affixation, e.g. the -ngay-affix in Dyirbal or the ine- prefix in Chukchi; a noun-verb agreement (typically accompanied by changes in case-marking and/or an addition of a verbal marker); and finally, word-order.

Although it seems that morphological or discourse effects alone may not suffice to identify an antipassive construction, the hierarchical demotion of the object, to a non-core or nonargument, plays a definitional role. In the situation when the object is downgraded or omitted, and that is the case in antipassives, it is natural for the agent to become the only salient participant of the event. As such, antipassive yields low-individuation interpretation of the object participant (indefinite, non-specific) and one of its recurrent properties includes imperfective interpretation (Polinsky, 2017, p. 310).

That leads us to the notion of aspect, a category which plays an important role in many areas of linguistic studies such as verb morphology, predicate syntax as well as semantics. Also various works on transitivity suggest that aspectual notions (including measure, delimiter, incremental theme, telicity and accomplishment, depending on the author) may constitute semantic determinants of argument realization ${ }^{2}$. Observations included in these works prompted theories implying that argument realization may be aspectually driven. Following this line of thought, this article presents the results of corpus-based studies on antipassive structure in the Polish language and makes an attempt at confirming the fact that aspectual notion may determine argument realization.

Numerous linguistic works in the field of transitivity point out that aspectual notions may constitute a determinant affecting the argument realization in a verbal structure. ${ }^{3}$ Furthermore, observations based on the examination of the antipassive material culled from the National Corpus of Polish (henceforth, NKJP) and the corpus of Wielki Słownik Języka Polskiego (heneceforth, KWSJP) go along similar lines.

Corpus antipassive examples may be divided into the following main categories: absolutive antipassive (which may be split further into antipassive with aggressive verbs (1), absolutive antipassive with a default object type 1 (2), i.e. with an object highly lexicalized in the verb

2 For more on aspectual notions, see inter alia Hopper and Thompson (1980) (an early discussion of the role aspect plays in argument realization), Centineo (1986), Dowty (1991), Van Valin (1990), Zaenen (1993) (how telicity is implicated in the unaccussative diagnosis), Fellbaum (1987), Tenny (1987, 1994) (passive nominals), Tenny (1987, 1994) (middle formation) and Dowty (1991), Tenny (1987) and van Hout (1996) (argument alternations).

3 See inter alia Wierzbicka (1967). 
meaning and type 2 (3), i.e. with the object being highly dependent on the context) and last but not least antipassive with an object demoted to an oblique case $(4)^{4}$.

(1) Proszę Pani, a on się bije. excuse me madam but he SIE fight3SG.PRES.IMPERF

'Excuse me, madam, he is fighting (other children).'

(2) Kury niosły się dwa razy dziennie.

henPL.F.NOM lay3PL.PST SIĘ two times daily.

(NKJP)

'Hens laid eggs twice a day.'

(3) Studenci bronili się dwa razy.

studentPL.M.NOM defend3PL.PST SIĘ two times.

'Students defended [their thesis] twice.'

(4) Pytał się o drogę na poste restante.

ask3SG.PST SIE about waySG.F.ACC to poste restanteSG.N.ACC

(NKJP)

'He asked the way to the poste restante.'

Analyzed corpus examples consistently limit the occurrence of absolutive antipassive with aggressive verbs to imperfective forms only, whereas the other types of antipassive structures are attested both in the imperfective and the perfective form. It seems that the there are certain factors at play which block the perfective aspect in absolutive antipassive with aggressive verbs and allow it in other types of antipassive structures. In this article we suggest that a solution to this antipassive aspectual puzzle may be linked to various projections coded in a verb. This kind of reasoning was presented in Ramchand (2008) who claimed that verbs may code three types of projections, i.e. the causing projection, the process projection and the result projection. Some verbs host all three projections, whereas others may lack a specific projection.

In our opinion aggressive verbs possess only two of the aforementioned projections, i.e. the causing (initP) and the process projection ( $\operatorname{proc} P$ ), lacking the result projection (resP), which limits the occurrence of absolutive antipassive with these verbs to the imperfective form only. Other types of antipassive structures are based on verbs which consist of all three projections, what allows us to use them in both the imperfective and perfective form.

\section{Notions of aspect}

Tense and aspect functionally interweave, although they are distinct grammatical categories. Being a deictic category, tense is used to signal temporal relations between events; aspect, on the other hand, is a non-deictic category which flags difference in the perspective the speaker takes to describe events. Depending on aspectual features of a verb (phrase), the point of view of the speaker changes (Grzegorczykowa et al., 1999, p. 154).

Aspect is a category which plays an important role in many areas of linguistic studies such as verb morphology, predicate syntax as well as semantics. Although it constitutes such a major

\footnotetext{
4 See Mroczyńska (2015) for a more detailed overview of types of antipassive structures attested in Polish.
} 
issue and it has been researched by several generations of specialists in the field, it still stirs many controversies and is regarded as a highly complicated and challenging issue both in Polish itself and in Slavonic languages in general (Szymanek, 2010, p. 128n).

Matthews (2005) provides a relatively vague, yet universal definition of aspect, claiming that aspect refers to

general term, originally of specialists in Slavic languages, for verbal categories that distinguish the status of events, etc. in relation to specific periods of time, as opposed to their simple location in the present, past or future (Matthews, 2005, p. 27).

Depending on a language, various aspectual propositions are distinguished e.g. progressive, durative, habitual, iterative, punctual, perfective or imperfective. For Polish, the perfective imperfective binary opposition is of key importance as contrasts and changes relating to perfectivity define the parameters of aspect in this language (Szymanek, 2010, p. 129).

As Svenonious argues "perfective verbs express an event as a bounded whole, while the imperfective may express an event which is ongoing or otherwise not distinctly bounded" (Svenonious, 2004, p. 179). This opposition may also be presented as completed versus incompleted (ongoing), for perfective and imperfective respectively. Another view is devised in Kuryłowicz (1977) where the contrast between an imperfective and perfective aspect is regarded as the opposition of an action seen in the course of happening and an action viewed as completed.

Here a question arises, i.e. what the scope of the perfectivity phenomena is, or in other words, which classes of verbs are subject to perfectivization and which verbs may participate in aspectual pairs. It seems that only telic verbs, i.e. those which imply a clear-cut end point and are inherently terminative, may be marked for aspect alone e.g. budować and $z$-budować 'to build' (Szymanek, 2010, p. 130). ${ }^{5}$ It seems that aspect is a feature already gramaticalized in Polish, which means that in the vast majority of cases the verb that occurs in a syntactic structure is either perfective or imperfective and we have appropriate formal tests at hand which can help us diagnose the aspect of a verb in a given proposition (Willim, 2006, p. 178).

What is more, it turns out that pure aspectual pairs, i.e. pairs where the two forms of a verb differ in a [+/- perfectivity] feature only and the lexical meaning is retained, are relatively restricted. In turn, the cases when perfectivity co-exists with some additional features changing the semantics of the verbs are much more widespread. Thus, if we take into consideration not only a pure aspectual change but also Aktionsart, i.e. the lexical aspect, all verbs in Polish will be overtly marked for perfective/imperfective aspect e.g. pisać - na-pisać 'to write, imperf./perf." (Szymanek, 2010, p. 132).

\footnotetext{
5 Cf. Willim (2006, p. 179), Grzegorczykowa et al. (1999, p. 161ff) and more recently Bloch-Trojnar (2015) for discussion concerning the correspondence between telicity and perfectivity in Polish.
} 


\section{Perfectivizing verbal prefixes in Polish}

In general, Slavonic verbal prefixes change the aspect of the verb to which they are attached. As may be expected, with highly productive prefixation, Polish is not an exception and the operation leads to changing the aspect of the verb from imperfective to the perfective ${ }^{6}$. When the only effect of adding a prefix is the change of aspect, the prefix is purely perfectivizing.

Polish examples of pure aspectual pairs are given in (5) and (6) for transitive verbs and in (7) for an intransitive verb.
a. Czytałam
(książkę).
read1SG.PST.IMPERF bookSG.F.ACC
'I was reading a book.'
b. Przeczytałam książkę.
PRZE-read1SG.PST.PERFbookSG.F.ACC
'I read a book.'
(6) a. Pisałam (adres).
write1SG.PST.IMPERF addressSG.M.ACC
'I was writing the address.'
b. Napisałam adres.
NA-write1SG.PST.PERF addressSG.M.ACC
'I wrote the address.'
(7) a. Kwiaty kwitly.
flowerPL.M.NOM bloom3PL.PST.IMPERF
'Flowers were blooming.'
b. Kwiaty zakwitly.
flowerPL.M.NOM ZA-bloom3PL.PST.PERF
'Flowers started to bloom.'

It is worth noting that in the case of transitive verbs the direct object may be left out when the verb is imperfective (as indicated by the round brackets () around a direct object in (5a) and (6a)), and it must be kept when the verb is perfective as in (5b) and (6b). It seems that a similar relation may be observed for aggressive verbs which may occur in antipassive, where the DO is left out and replaced by the marker sie, only when the verbs has a [- perfective] feature.

There is a major complication concerning aspect, which is the relationship between grammatical aspect (the purely perfectivizing/imperfectivizing role of prefixing) and Aktionsart, i.e. lexical aspect. ${ }^{7}$ As Gawrońska argues Actionsart in Polish may be regarded as "a semantic category which characterizes the internal spatiotemporal structure of an event and/or the relations between the event itself, its cause and/or its result" (Gawrońska, 2001, p. 3). In the examples above, which illustrate purely perfectivizing results of prefixing the verb, read takes the prefix PRZE-, write NA- and bloom ZA-. Instances where adding a prefix changes also the

\footnotetext{
6 See Medová (2009, p. 31) for discussion of the phenomenon in Czech.

7 See Młynarczyk (2004) for an overview of the concept of aspect and Aktionsart in Slavonic languages.
} 
meaning of the verb are presented below and the intended reading is indicated in glosses. For convenience $(6 \mathrm{~b})$ is repeated as $(8 \mathrm{a})$ below, and $(7 \mathrm{~b})$ as $(9 \mathrm{a})$ below.

(8) a. Napisałam adres.

NA-write1SG.PST.PERFaddressSG.M.ACC

'I wrote the address.'

b. Przepisałam adres.

PRZE-write1SG.PST.PERF addressSG.M.ACC

'I rewrote the address.'

c. Zapisałam adres.

ZA-write1SG.PST.PERF addressSG.M.ACC

'I wrote down the address.'

d. Dopisałam adres.

DO-write1SG.PST.PERF addressSG.M.ACC

'I (additionally) wrote the address.'

(9) a. Kwiaty zakwitly.

flowerPL.M.NOM ZA-bloom3PL.PST.PERF

'Flowers started to bloom.'

b. Kwiaty rozkwitly.

flowerPL.M.NOM ROZ-bloom3PL.PST.PERF

'Flowers bloomed in full.'

c. Kwiaty przekwitly.

flowerPL.M.NOM PRZE-bloom3PL.PST.PERF

'Flowers finished blooming.'

As Medová (2009, p. 32) argues for Czech, certain prefixes or verb combinations both for (originally) transitive and intransitive verbs require that clitic SE is used obligatorily. It seems that the same, i.e. the compulsory application of the marker sie, may be necessary in Polish. This brings us to an interesting issue, i.e. how various perfectivizing prefixes combine with the marker się in Polish and what consequences it has regarding the process of antipassivization.

\subsection{Prefix ROZ-}

As Szymanek argues the prefix roz-is locative/directional and is frequently encountered in predicates which denote 'the parting and dispersion, in different directions, of people or things, in relation to some implicit central location' (Szymanek, 2010, p. 166).

Certain Polish load verbs such as pakować, składać may be prefixed with roz-. As in (10), the verb rozłożyć may be used with a direct object in its canonical accusative case as in (10b) or it may be followed by the marker sie as in (10c) where the direct object shifts to an oblique case i.e. prepositional locative case. (10c) is taken from NKJP, (10a), (10b) and (10d) are provided by the author to contrast the use of a base verb, a prefixed verb both in its perfective and imperfective aspect and a prefixed verb followed by the marker sie, respectively. As it may be seen from (10c) and (10d) below, prefix roz-is productive both for the perfective and 
imperfective form of the verb, i.e. złożyć - rozłożyć and składać - rozkładać, respectively. In both cases the occurrence of się imposes the shift of direct object case as described above.

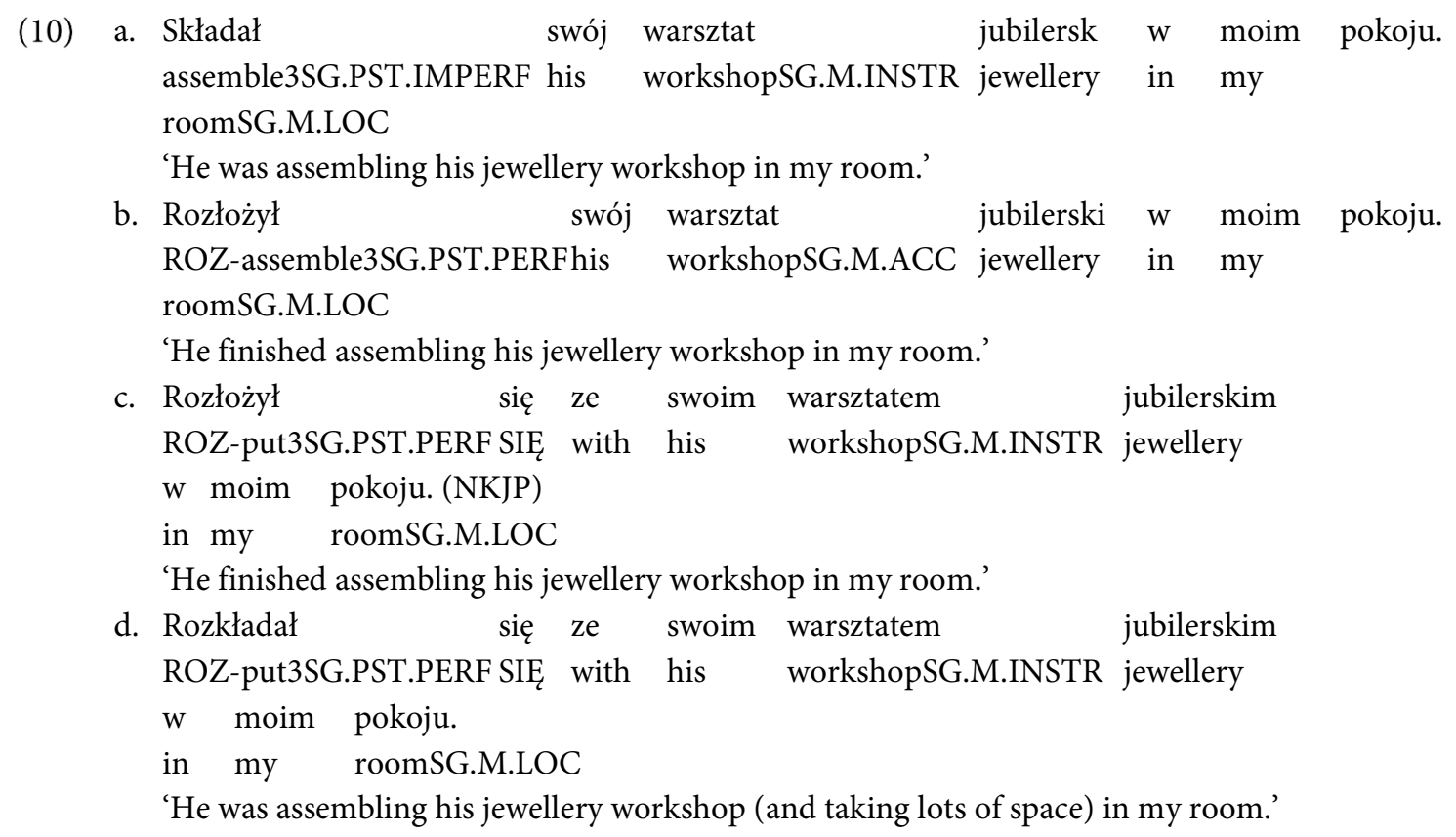

Corpus-based examples including the verb rozkładać where a direct object is left out may also be attested as in (11). The presence of SIE seems to be obligatory in such contexts.

\begin{tabular}{|c|c|c|c|}
\hline (11) & $\begin{array}{ll}\text { Można } & \text { bez } \\
\text { canIMPERS } & \text { without }\end{array}$ & $\begin{array}{ll}\text { obawy } & \text { zabrać } \\
\text { fearSG.F.GEN } & \text { takeINF }\end{array}$ & $\begin{array}{l}\text { grilla } \\
\text { barbecueSG.M.ACC }\end{array}$ \\
\hline & i $\quad$ kiełbaski & rozłożyć się w & tym parku. (NKJP) \\
\hline & and sausagePL.F.ACC & ROZ-put SIE in & parkSG.M.LOC \\
\hline
\end{tabular}

The ROZ- prefixed verbs, which require an obligatory SIE and an object in an oblique case as in (10), seem to fall into the category of antipassive with an oblique object. Whereas (11) with a missing object shows a clear resemblance to antipassive with a default object type 2 .

\subsection{Prefix NA-}

This prefix may host several semantic functions and the cumulative function is the one of interest in this work. In this sense the prefix often denotes "high intensity and/or considerable effort put into the activity itself, which may be deemed excessive' (Szymanek, 2010, p. 150). The occurrence of the prefix in the latter use usually requires the presence of się and the meaning of the proposition is 'to one heart's content" e.g. napić się (to drink to one's heart content). Thus, adding the prefix na- not only does result in the change of aspect but it also leads to the additional change of the verb meaning.

Transitive verbs that take part in such a derivation include: 


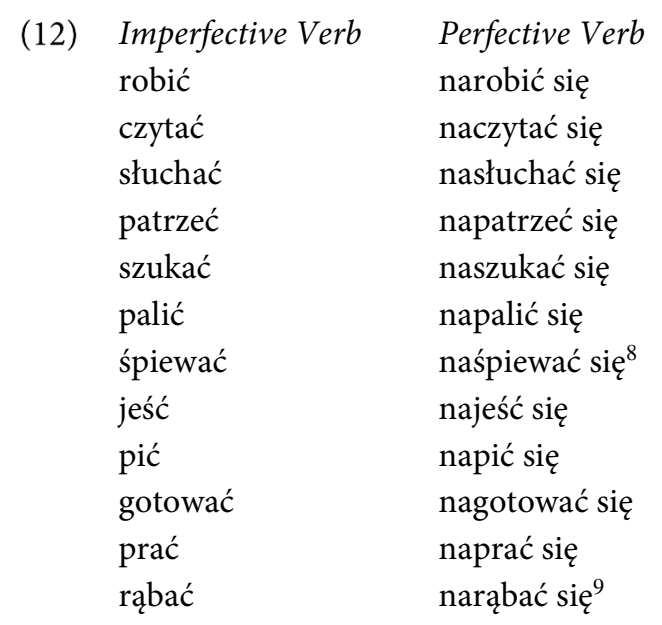

Examples (13a)-(23a) culled from the NKJP contain prefixed transitive verb forms and are usually contrasted with author's own examples including respective unprefixed forms of the verbs listed in (12). As it may be noticed based on the examples presented below, prefixation may lead to the change of the case of an object as in (14), or it may cause no change of the case of the object when in the imperfective sentence the object is originally oblique as in (15) and (17). Moreover, in some instances, as in (13), the object may be dropped both in the imperfective and in the perfective sentence; however, the missing object may probably be recreated based on the context for a given utterance.
a. Naczytał
się, nasłuchał,
napatrzył.
NA-read3SG.PST.PERF SIĘ NA-listen3SG.PST.PERF NA-look3SG.PST.PERF

(NKJP)

'He read, listened to and looked at (it) a lot.'

b. Czytał, słuchał, patrzył.

read3SG.PST.IMPERF listen3SG.PST.IMPERF look3SG.PST.IMPERF

'He was reading, listening to and looking at (it).'

(14)

a. Mały Jasio

naczytał

się podręczników

historycznych.

(NKJP)

little JohnSG.M.NOM NA-read3SG.PST.PERF SIĘ textbookPL.M.GEN history

'Little John read a lot of history textbooks.'

b. Mały Jasio czytał podręczniki historyczne.

little JohnSG.M.NOM read3SG.PST.IMPERF textbookPL.M.ACC history

'Little John read a lot of history textbooks.'

(15) a. Naczytali się o rozmaitych oszustwach i przekrętach. (NKJP) NA-read3SG.PST.PERF SIĘ about various fraudPL.N.LOC and scamPL.M.LOC

'They read a lot about various frauds and scams.'

b. Czytali o rozmaitych oszustwach i przekrętach.

read3SG.PST.PERF about various fraudPL.N.LOC and scamPL.M.LOC

'They were reading about various frauds and scams.'

8 Szymanek, 2010, p. 150.

9 Szymanek, 2010, p. 150. 
(16)

a. Inspektor nasłuchał się opowieści

inspectorSG.M.NOM NA-listen3SG.PST.PERF SIĘ storyPL.F.GEN

o trudnym dzieciństwie.

about difficult childhoodSG.N.LOC

(NKJP)

'The inspector listen to a lot of stories about difficult childhood.'

b. Inspektor słuchał opowieści

inspectorSG.M.NOM listen3SG.PST.PERF storyPL.F.GEN

o trudnym dzieciństwie.

about difficult childhoodSG.N.LOC

'The inspector was listening to stories about difficult childhood.'

(17) a. Ludzie nasłuchali się o podatku VAT.

personPL.M.NOM NA-listen3PL.PST.PERF SIE about taxSG.M.LOC VAT

(NKJP)

'People listened (to a lot of information) about the VAT.'

b. Ludzie słuchali o podatku VAT.

personPL.N.NOM hear3PL.PST.IMPERF about taxSG.M.LOC VAT

'People were listening (to information) about the VAT.'

(18) a. Napatrzył się na ludzkie dramaty.

(NKJP)

NA-look3SG.PST. PERF SIĘ on human tragedyPL.F.ACC

'He looked a lot at human tragedies.'

b. Patrzył na ludzkie dramaty.

look3SG.PST.IMPERF on human tragedyPL.F.ACC.

'He was looking at human tragedies.'

(19) a. Czy nie narobiła się dość w życiu?

QW NEG NA-work3SG.F.PST.PERF SIĘ enough in lifeSG.N.LOC

'Didn't she work hard enough on her life?'

b. Czy nie robiła dość w życiu?

QW NEG work3SG.F.PST.IMPERF enough in lifeSG.N.LOC

'Wasn't she working enough in her life?'

(20) a. Narobił się w sadzie.

(NKJP)

NA-work3SG.M.PST.PERF SIĘ in orchardSG.M.LOC

'He worked a lot in the orchard.'

b. Robił (różne rzeczy) w sadzie.

work3SG.M.PST.IMPERF (various things) in orchardSG.M.LOC

'He was working/worked in the orchard.'

c. Narobił się, naszukał, wkońcu dwie znalazł,

NA-work3SG.PST.PERF SIĘ NA-seek3SG.PST.PERF and finally two find3SG.PST.PERF

$\begin{array}{llllll}\text { najpierw się } \mathrm{z} \text { jedną } & \text { ożenił, } & \mathrm{z} & \text { drugą. } & \text { (NKJP) }\end{array}$

first SIE with oneSG.F.ACC marry3SG.PST.PERF then with anotherSG.F.ACC

'He worked a lot, seek a lot and finally he found two; first he married one and then another.'

(21) a. Napalił się głupol papierosów

NA-smoke3SG.PST.PERF SIĘ stupid cigarettePL.M.ACC

a później mówi, że on bardzo chory [...].

and then say3SG.PRES that he very ill

(NKJP)

'He, stupid, has smoked a lot of cigarettes, and then he says he's very ill.' 
b. Palił papierosy.

smoke3SG.PST.IMPERFcigarettePL.M.ACC

'He was smoking cigarettes.'

(22) a. [..] najadł się surowej kapusty.

(KWSJP)

[...] NA-eat3SG.PST.PERF SIE raw cabbageSG.F.GEN

'He ate too much/ a lot of raw cabbage.'

b. Najadł się pan? Dobre było, co?

NA-eat3SG.PST.PERF SIĘ sir good be3SG.PST huh

'Have you eaten (enough)? It was good, huh?'

c. Jadł

surową kapustę.

eat3SG.PST.IMPERF raw cabbageSG.F.ACC

'He was eating raw cabbage.'

(23) a. Gdy usiedli, zapytał, czy napiją się kawy.

when sit3PL.PST ask3SG.PST if NA-drink 3PL.FUT SIE coffeeSG.F.GEN

'When they sat down, he asked if they would have some coffee.'

b. A napić się możemy.

and NA-drink INF SIE can1PL.PRES

'And we can have a drink.'

c. Zwykle piją kawę rano.

usually drink3PL.PRES.IMPERF coffeeSG.F.ACC morning

'They usually drink coffee in the morning.'

The examples presented above lead us to another interesting problem relating to the prefix $n a-$, i.e. its interrelation with quantificational marking on the direct object. It seems that if the prefix is used with the verbs of consumption such as jeść 'eat' or pić 'drink' (when it is interpreted as quantificational, and not accumulative in nature), it does not impose the size of the quantity consumed. However, it puts certain restrictions on the direct object, i.e. it requires the genitive marked expression and it is limited solely to bare mass or plural nouns; countable singular nouns are not found in the object position. However, the count singular noun in a default accusative case is possible when the object argument is expressed as an explicitly measured amount consumed as in e.g. napić się kieliszek koniaku 'drink a glass of cognac' or zjeść kawałek ciasta 'eat a piece of cake'.

A similar pattern, i.e. prefixing the verb with NA-, yet not attested in NKJP or KWSJP, seems to apply to verbs relating to housework such as gotować 'to cook', prać 'to wash', where the na-prefixed verb means 'to spend much time doing the cooking or washing' and it must be followed by the marker się (the prefixed verb forms with the marker się are given as separate entries in the online version of Słownik Języka Polskiego $\mathrm{PWN}^{10}$ ). The illustrative propositions given below are based on author's own linguistic competence.
a. Gotowała
zupę
wczoraj.
cook3SG.PST.IMPERF
soupSG.F.ACC yesterday
'She was cooking soup yesterday.'

${ }^{10} \mathrm{http}: / / \mathrm{sjp} \cdot \mathrm{pl} /$ 
b. Nagotowała się (zupy) wczoraj. NA-cook3SG. PST.PERF SIE (soup)SG.F.GEN yesterday

'She spent a lot of time cooking (soup) yesterday.'
a. Prała
(koszule)
wczoraj.
wash3SG.PST.IMPERF (shirts)PL.F.ACC yesterday
'She was doing the washing yesterday.'

b. Naprała się (koszul) wczoraj.

NA-wash3SG.PST.PERF SIE (shirt)PL.F.GEN yesterday

'She washed a lot of shirts yesterday.'

Szymanek also lists verbs rąbać - narąbać się and śpiewać - naśpiewać się as examples of derivation showing 'doing something to one's heart content' (Szymanek, 2010, p. 150). NKJP and KWSJP do not provide any instances of propositions with these perfective verbs, and simple transitive examples below are based on author's own linguistic competence.
a. Rąbał
drewno
wczoraj rano.
chop3SG.PST.IMPERF woodSG.N.ACC yesterday morning
'He was chopping wood yesterday morning.'
b. Narąbał się (drewna) wczoraj rano.
chop3SG.PST.PERF SIĘ woodSG.N.GEN yesterday morning
'He chopped a lot of wood yesterday morning (and probably he was tired).'

The addition of the prefix na- to the verb rabać requires the presence of sie and the direct object may either be omitted or its case shifts to oblique (a genitive case). The fact that the antipassive reading is highly context-dependent is perfectly illustrated by the verb narąać się. The omission of DO is possible providing that it is clear from the context that the activity refers to chopping (wood), as narąbać się is also an intransitive verb which carries a different meaning, i.e. 'to drink too much'.

Indicating an action 'done to one's heart content' with supplementing the na- prefix may also be illustrated with example (27) below based on the verb śpiewać.
(27)
a. Śpiewał piosenki. sing3SG.PST.IMPERF songPL.N.ACC 'He was singing songs.'
b. Naśpiewał się (piosenek). NA-sing3SG.PST.PERF SIE songPL.F.GEN 'He sang a lot of songs.'

As for narąbać się, in the case of naśpiewać się, the verb may either be followed by DO in oblique or DO is dropped altogether and as such they will fall into the category of antipassive with an oblique object or an antipassive with a default object type 2 respectively. Other verbs that may be prefixed with NA- seem to behave in a similar manner. 


\subsection{Prefix $O-/ O B-$}

Among other uses, this prefix conveys the idea that a particular activity is of high intensity, has abundant results or is excessive. This meaning may be particularly frequently noticed in colloquial speech where verbs such as obkupić się 'to buy a lot of things', obkuć się 'to swot a lot', objeść się 'to stuff oneself or obeżreć się 'to gorge onself are used (Szymanek, 2010, p. 153).

In her discussion concerning verbs that may undergo antipassivization, Janic argues that excessive consumption verbs such as objeść się 'to stuff oneself or opić się 'drink too much' constitute a problematic case as the use of the notion of antipassive here is justified only to a certain degree (Janic, 2013, p. 169). This is due to the fact that the derivations of the type jeść objeśc się and pić - opić się meet the antipassive requirement so as not to change the semantic roles of the arguments, but they clearly modify the semantic properties of arguments.
a. Dziecko
piło
wodę. ${ }^{11}$
childSG.NEUT.NOM drink3SG.PST.IMPERF waterSG.F.ACC
'The child was drinking water.'
b. Dziecko opiło się wodą.
childSG.N.NOM drink3SG.PST.PERF SIE waterSG.F.INSTR
'The child has drunk too much water/a lot of water.'

In (28b) where the verb has the $o$ - prefix indicating an excessive action and also a perfective aspect, the agent is also affected by the effects of the action; the child had a lot/too much to drink and either feels unwell or is not thirsty. Janic (2013, pp. 169-170) treats this type of verbs as a particular case of employing the antipassive structure since they do not fit into the definition of the prototypical antipassive where the action is unidirectional and is directed to the patient, not affecting the agent. Here the action is also directed to the agent, which may suggest a reflexive reading.

Although Janic mentions only the verb pić - opić się, jeść - objeść się (eat - stuff oneself) presents a similar case.
a. Dziecko jadło ciasto.
childSG.N.NOM eat3SG.PST.IMPERF cake SG.F.ACC
'The child was eating cake.'
b. Dziecko objadło się ciastem.
childSG.N.NOM eat3SG.PST.PERF SIĘ cakeSG.F.INSTR
'The child has eaten too much cake/a lot of cake.'

NKJP provides further similar examples where the use of prefix $o$ - and the marker sie is attested.

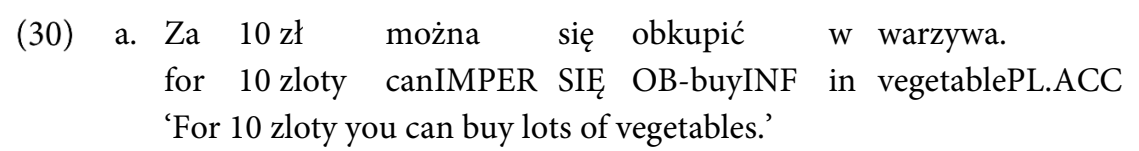

11 (98) after Janic, English translation ${ }_{[\mathrm{KM}]}$. 
b. Nie lubię obkupować się $\mathrm{w}$ supermarkecie.

NEG like1SG.PRES OB-buy SIE in supermarketSG.M.LOC

(31) a. Trzeba się więc będzie obkuć,

have toIMPER SIE so be3SG.FUT swotINF

bo wczorajsze święto "kotów"

because yesterday festivalSG.N.NOM freshmanPL.M.GEN

kończyło okres ochrony.

(NKJP)

end3SG.PST periodSG.M.ACC protectionSG.F.GEN

'You'll have to swot because yesterday's freshman's festival marked the end of the protection period.'

b. Na studiach musieliśmy obkuwać się przed każdym egzaminem.

on studyPL.LOC must1PL.PST OB-swot SIĘ before every examSG.M.INSTR

(32) a. Jadę obeżreć się szwajcarską czekoladą,

go1SG.PRES OB-gorgeINFSIĘ Swiss chocolateSG.F.INSTR

tatarską chałwą i tureckimi bakaliami.

(NKJP)

Tatar halvaSG.F.INSTR and Turkish dried fruitPL.INSTR

'I'm going (there) to stuff myself with Swiss chocolate, Tatar halva and Turkish dried fruit.'

b. Nie można się obżerać

NEG canIMPER SIĘ OB-stuffINF.IMPERF

i pić trzeba $\mathrm{z}$ umiarem.

and drinkINF have toIMP with moderationSG.M.INSTR

'You mustn't stuff yourself and you should drink moderately.'

(NKJP)

Summing up, the perfective prefix $\mathrm{OB}$ seems to consistently indicate an excessive action and the OB- prefixed verbs listed in Szymanek (2010, p. 153) may have corresponding imperfective forms, e.g. obeżreć się - obżerac się, obkupić się - obkupować się, obkuć się obkuwać się, objeść się - objadać się. Both the perfective and imperfective verbs seem to behave in the same manner as far as their direct object is concerned. Moreover, in both aspectual forms the presence of sie is required and the direct object itself is either left out or shifted to oblique. The compulsory presence of sie and clear backgrounding of the object, either by omitting it completely or by shifting it to an oblique case, are features of antipassive structures. Thus, the examples containing NA-prefixed verbs presented above seem to correspond with antipassive structures with default object type 2 (the DO may be recreated based on the context) and antipassives with an oblique object, respectively.

\subsection{Prefix $U$ -}

As Szymanek claims the prefix $u$ - may be found "in only a few consistent semantic patterns of lexical perfective verbs" (Szymanek, 2010, p. 169). One of the minor classes Szymanek distinguishes when analyzing verbs with the prefix $u$-conveys the meaning 'to be able to, to manage' and consequently, the verbs connote difficulty performing an action (Szymanek, 2010, p. 170). This class includes several verbs that may be analyzed in terms of antipassivization e.g. uchwycić 'to grip' or utrzymać' to hold'. 
(33)

\begin{tabular}{|c|c|c|c|}
\hline $\begin{array}{l}\text { Chłopak } \\
\text { boySG.M.NOM }\end{array}$ & $\begin{array}{l}\text { ledwo } \\
\text { hardy }\end{array}$ & $\begin{array}{l}\text { zdołał } \\
\text { manage3SG.PST }\end{array}$ & $\begin{array}{ll}\text { uchwycić } & \text { się } \\
\text { U-gripINF } & \text { SIĘ }\end{array}$ \\
\hline
\end{tabular}

(NKJP) "The boy hardly managed to grip the line."

$\begin{array}{lllll}\text { Dwoma } & \text { palcami } & \text { uchwyciła pręt } & \text { i szarpnęła mocno. } \\ \text { two } & \text { fingerPL.M.INSTR } & \text { U-grip3SG.PST rode SG.M.ACC } & \text { and } & \text { pull3SG.PST hard } \\ \text { 'Using two fingers, she gripped the rode and pulled hard.' } & \end{array}$

'Using two fingers, she gripped the rode and pulled hard.'

The verb uchwycić can be used with an accusative object or, when used with the marker się, it requires the change of object case to the genitive. As Janic (2013, pp. 164-165) claims, this shift does not affect the semantic roles of the arguments as opposed to the verb chwycic where, as she argues, there is a change of semantic roles. The shift of the case of a direct object and the presence of sie also changes the focus of attention, moving it towards the Agent and its activity and away from the Patient, which is a characteristic feature of antipassive structures. The fact that it is the Agent's ability which is in the foreground is particularly clearly seen in (33) above where the idea is emphasized lexically by the verb $z$ dołat 'to manage to'.

\section{Aspect and the antipassive reading of a structure}

It seems that the four types of antipassive distinguished above i.e. absolutive antipassive, absolutive antipassive with default object type 1, absolutive antipassive with default object type 2 and antipassive with an oblique object, may be analyzed in terms of antipassive derivations. The NKJP examples illustrating different types of derivations share the same features that are attributed to antipassive constructions. They are syntactically intransitive as the realization of the patient is blocked by the marker sie. However, the patient is still present at the semantic plane (it is either unspecified or generic or it may be recreated based on contextual information). Moreover, the two propositions, the transitive one and the intransitive one, are synonymous at the denotational level. The number of implied arguments (participants) remains unchanged and therefore, the action remains semantically transitive.

As for perfectivity, the NKJP example (1) provided above suggest that aggressive verbs yield to antipassive interpretation as long as they occur in an imperfective form, whereas perfective aspect blocks the possibility of antipassive interpretation. In the case of antipassive with default object type 1 and type 2 , a perfective prefix used with the verb imposes certain requirements on the argument structure of the verb it combines with. Firstly, excessive prefixes such as NA- or $\mathrm{O}-/ \mathrm{OB}$ - appear obligatorily with the marker się. Secondly, when the verb has a direct object of its own, the direct object is either omitted (as shown in (24b) nagotować się and (25b) naprać się) or it becomes oblique (as shown in (29b) in the case of objeść się). In turn, when the direct object is (originally) oblique adding się seems to be only stylistic in nature and it does not lead to any changes in the argument structure (as shown in (15) or (17)).

We suggest that aspect related to distribution of antipassive reading of a structure is linked to the projections coded in a verb ${ }^{12}$. Aggressive verbs such as kopać ('kick') or bić ('fight') code

\footnotetext{
12 See Ramchand (2008) for a detailed analysis of verbal projections.
} 
only the causing and process projections but do not host a result projection as in (35) illustrating the sample sentence (36) below.

(35)

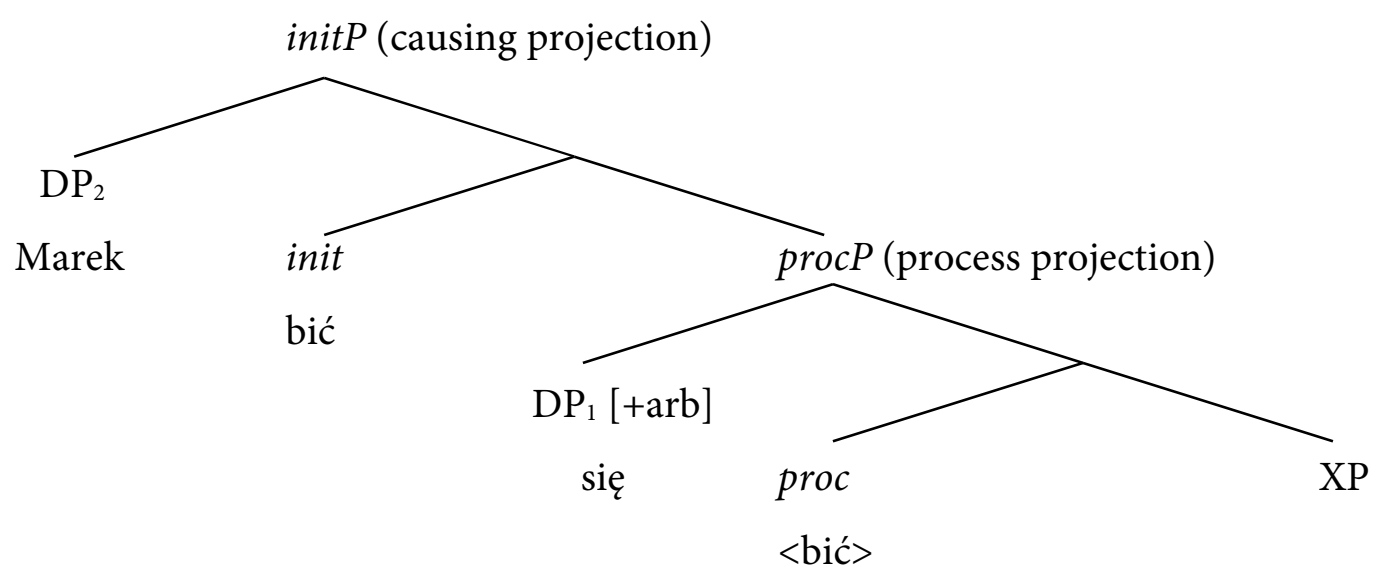

(36) Marek się bije.

Mark SIĘ fight3SG.PRES.IMPERF

'Mark fights with other children.'

We assumed that an aggressive verb such as bić is specified as [init, proc], i.e. it has a lexical encyclopedic content that identifies a process and conditions of initiation (causing). The event building is a recursive process so starting from the bottom of the syntactic representation in (35), the verb bić will merge with a DP in its specifier and project its proc label. Moreover, as bić has an init feature it can now be remerged with $\operatorname{proc} P$, which in turn projects the init label. We get a new syntactic object which then merges with the specifier to project init $P$. In our structure $\mathrm{DP}_{2}$ corresponds to the initiator (Marek) and $\mathrm{DP}_{1}$ to an undergoer (the arbitrary object, other people in general, here expressed in form of się), XP corresponds to the complement of the process head which in our example in not overtly specified but may be filled in by a contextual variable.

The other verbs participating in antipassive alternations such as antipassive with default object type 1 or type 2 do not refer to any specific characteristics of agents but rather to certain processes they perform. When analyzing verbs such as pakować 'pack', which may occur in imperfective and perfective antipassive, we will argue that the lexical content of the verb in the meaning as used in the antipassive construction is [init, proc, res]. For this kind of verbs the DP object is both in the function of the undergoer and the resultee, and the verb comprises three causationally related subevents. This is represented in (37) below illustrating the sample sentence (38). 
(37)

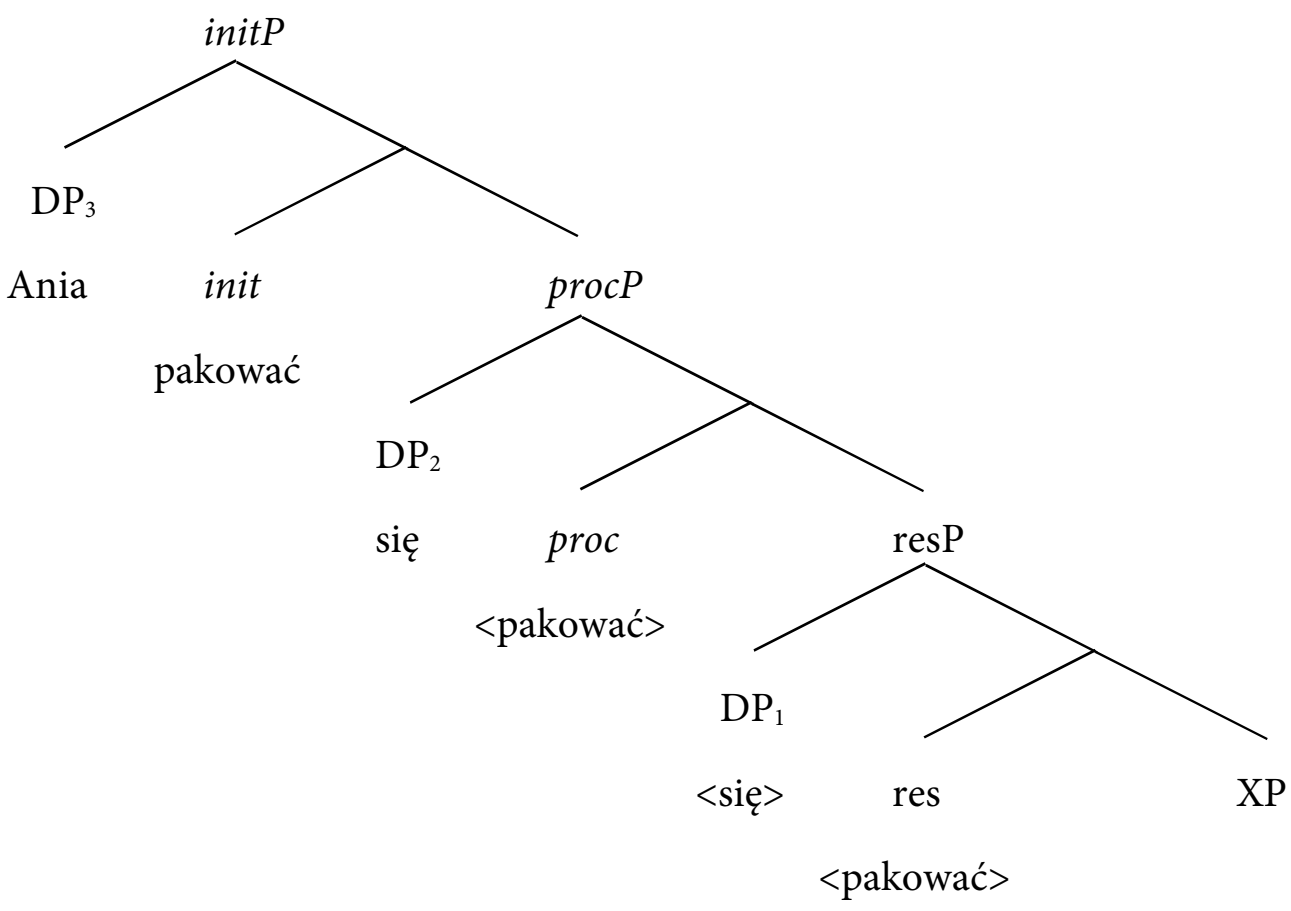

(38) a. Ania pakuje się (do walizki).

Ann pack3SG.PRES.IMPERF SIĘ (into suitcase)SG.F.GEN

'Ann is packing her things (into a suitcase).'

b. Ania spakowała się (do walizki).

Ann pack3SG.PST.PERF SIĘ (into suitcase)SG.F.GEN

'Ann packed her things (into a suitcase).'

According to Ramchand (2008), the diagnostic for initiation-process-result verbs is the fact that they can take simple locational state prepositions as the rhematic complement of the result projection to describe the final result. Examples (38a) and (38b) above may be supplemented with such a locational state preposition.

In the case of initiation-process-result verbs such as pakować 'pack' the DP object undergoes the verbal process which leads to the final state or location as described by the prepositional phrase in round brackets in (38); the things Ann is packing end up in a suitcase, for example. According to Ramchand (2008, p. 83), the prepositional phrase denoting a static location should appear in the complement of the stative result projection. The result head seems to be able to appear both in the imperfective and the perfective form depending on whether the process is completed or not.

The prefixed verbs analyzed in section 2 of the article bear resemblance to the verb pakować 'pack' and also seem to code all three projections. Therefore, they may appear in the antipassive both in their imperfective and perfective form.

\section{Conclusion}

In conclusion, it seems that Polish displays a certain kind of interaction between aspect marking on the verb and the antipassive marker się. Aggressive verbs yield antipassive interpretation 
only when used in the imperfective form. This is probably due to the way projections are coded on the verb, i.e. in the case of aggressive verbs only causing and process projections are coded whereas the result is not, which blocks the perfective realization of antipassivized forms. As for the absolutive antipassive with default object type 1 and type 2, both the imperfective and perfective forms are allowed. However, a perfective prefix used with the verb imposes certain requirements on the argument structure of the verb it combines with.

The analysis of prefixes such as $n a$ - and $o$ - $/ o b$ - prompted some interesting observations regarding the interrelation between the verb affixation and the process of antipassivization. Firstly, excessive prefixes such as na- or $o$-/ob-appear obligatorily with the marker się. Secondly, when the verb has a direct object of its own, the direct object is either omitted (as shown in (24b) with the verb nagotować sie and (25b) with the verb naprać się) or it becomes oblique (as shown in (29b) with the verb objeść się). ${ }^{13}$ In turn, when the direct object is (originally) oblique adding się seems to be only stylistic in nature and it does not lead to any changes in the argument structure (as shown in (15) with naczytać się or (17) with nastuchać się). The compulsory presence of the marker sie as well as foreground of the Agent with a simultaneous backgrounding of the object are inherent features of antipassive structures. Thus, the examples with a missing direct object, e.g. (24b) or (25b), fall into the category of antipassive with default object type 2, whereas those where the direct object is shifted to an oblique, e.g. (29b), correspond to the antipassive with an oblique object.

Taking the above remarks into consideration, we may assume that the distribution of antipassive in Polish depends on the lexical meaning of the verb, and the projections which are coded in it, as well as some discourse related factors which may help us to interpret correctly the missing object arguments.

\section{References}

Bloch-Trojnar, M. (2015). Grammatical aspect and the lexical representation of Polish verbs. Poznań Studies in Contemporary Linguistics, 51(4), 487-510.

Centineo, G. (1986). A lexical theory of auxiliary selection in Italian. Davis Working Papers in Linguistics, 1, 1-35.

Dowty, D. (1991). Thematic proto roles and argument selection. Language, 67(3), 547-619.

Fellbaum, Ch. (1987). On nominals with preposed themes. Chicago Linguistic Society, 23, 79-92.

Gawrońska, B. (2001). PolVerbNet: An experimental database for Polish verbs. In J. Hutchins (Ed.), Proceedings of MT Summit VIII: Machine Translation in the Information Age, Santiago de Compostella (Spain), September 18-22, 2001. Retrieved from https://nats-www.informatik.uni-hamburg.de/intern/proceedings/2 001/MTSUMMITVIII/ Gawronska.pdf.

Grzegorczykowa R., Laskowski R., \& Wróbel H. (1999). Gramatyka współczesnego języka polskiego. Morfologia, 3rd edition, 151-224. Warszawa: Wydawnictwo Naukowe PWN.

Hopper, P., \& Thompson, S. (1980). Transitivity in grammar and discourse. Language, 56(2), 251-299.

Hout van, A. (1996). Event semantics of verb frame alternations. PhD dissertation. Tilburg University. Tilburg, The Netherlands.

Janic, K. (2013). L'antipassif dans les langues accusatives. PhD dissertation. Université Lumière Lyon 2. Lyon, France.

${ }^{13}$ As for objeść się or opić się it is also possible to omit the direct object completely as in Objadłam się, teraz boli mnie brzuch. 'I've stuffed myself and now I have a stomach ache.' 
Kuryłowicz, J. (1977). Problème de linguistique Indo-Européenne. Wrocław: Zakład Narodowy im. Ossolińskich Wydawnictwo Polskiej Akademii Nauk.

Matthews, P. H. (2005). Oxford concise dictionary of linguistics. Oxford: Oxford University Press.

Medová, L. (2009). Reflexive markers in the Slavic and Romance languages. A comparative view from an antipassive perspective. PhD Dissertation. Princeton University, Princeton, NJ, USA.

Młynarczyk, A. (2004). Aspectual pairing in Polish. PhD dissertation. Utrecht University: Utrecht, the Netherlands. (Retrieved from http://igitur-archive.library.uu.nl/dissertations/2004-0309-140804/inhoud.htm).

Mroczyńska K. (2015). On verb valency and the antipassive construction in the Polish language. In K. Kozak \& A. Rzepkowska (Eds.), Forum for Contemporary Issues in Language and Literature vol. II From word to discourse. Siedlce, Wydawnictwo IKR[i]BL.

Narodowy Korpus Języka Polskiego [The National Corpus of Polish]. (2012). A. Przepiórkowski, M., Bańko, R., Górski, and B. Lewandowska-Tomaszczyk (eds.), Wydawnictwo Naukowe PWN, Warszawa. http://korpus/pl

Polinsky, M. (2005). Antipassive constructions. In M. Haspelmath, M. Dryer, D. Gil et al. (Eds.), The world atlas of language structures (pp. 438-439). Oxford: Oxford University Press.

Polinsky, M. (2017). Antipassive. In J. Coon, D. Massam \& L. deMena Travis (Eds.), The Oxford Handbook of Ergativity (pp. 307-331). Oxford: Oxford University Press.

Ramchand, G. (2008). Verb meaning and the lexicon: A first phase syntax. Cambridge: Cambridge University Press.

Silverstein, M. (1976). Hierarchy of features and ergativity. In R. M. W. Dixon (Ed.), Grammatical categories in Australian languages (Coll. Linguistic Series 22) (pp. 112-171). Canberra: Australian Institute of Aboriginal Studies.

Szymanek, B. (2010). A panorama of Polish word-formation. Lublin: Wydawnictwo KUL.

Tenny, C. (1987). Grammaticalizing aspect and affectedness. PhD dissertation. MIT, Cambridge, USA.

Tenny, C. (1994). Aspectual roles and the syntax-semantics interface. Dordrecht: Kluwer.

Van Valin, R. D., Jr. (1990). Semantic parameters of split intransitivity. Language 66, 221-60.

Wielki stownik języka polskiego PAN, 2007. P. Żmigrodzki (Ed.), Instytut Języka Polskiego PAN, Kraków. http://www.wsjp.pl

Wierzbicka, A. (1967). On the semantics of verbal aspect in Polish. In To Honour Roman Jakobson. Vol. 3, 22312249. The Hague: Mouton.

Willim, E. (2006). Event, individuation and counatbility. A study with special reference to English and Polish. Kraków: Jagiellonian University Press.

Zaenen, A. (1993). Unaccusativity in Dutch: Integrating syntax and lexical semantics. In J. Pustejovsky (Ed.), Semantics and the lexicon (pp. 129-161). Dordrecht: Kluwer. 